\title{
Analisis Pengaruh Bauran Pemasaran Terhadap Kepuasan dan Loyalitas Pelanggan di Karita Muslim Square Yogyakarta
}

\author{
Richa Angkita Mulyawisdawati \\ STAI Al-Muhsin Krapyak Yogyakarta \\ Email:richa_angkita@yahoo.co.id
}

\begin{abstract}
Syari'ah marketing is a business discipline strategies that directs to the process of supply, demand and value alteration from an initiator to its stakeholders based on Islamic principles. And also about customer's satisfaction which is a basic concept of marketing and success factor for organization in business as well. It could be viewed from the fact that there are many companies emphasize the importance of giving their customers high level of satisfaction. Most companies measure the satisfaction of their customer and hope the customer will loyal in choosing the company's product or service, if the customer satisfaction is high. So that it would cause the customer's loyalty to the company.This research is attempted to measure the influence of marketing mix which are consist of four aspects product, price, location or distribution and promotion to the customer's satisfaction, then their accordance to Islamic Principles and to measure the influence of customer's satisfaction to customer's loyalty in Karita Muslim Square Yogyakarta. This research is an analytic descriptive research in quantitative and qualitative uses the
\end{abstract}

method of distributing questionnaire in order to gain primary data by non probability sampling technique for 100 respondents of the customer of Karita Muslim Square Yogyakarta. The result of this research shows that product and price significantly influence to the customer's satisfaction. But location or distribution gives the negative influence and doesn't significantly toward the customer's by the standardized coefficient value -0.26 , while promotion gives the positive influence but doesn't significantly toward customer's satisfaction by the significant value 0.467 > a (0.05). Price is the strongest aspect which gives the influence to customer's satisfaction by the significance value 0,000. Meanwhile, from simple regression it was proven that customer satisfaction positively influence loyalty intentions. Those four marketing mix which were offered by Karita Muslim Square have been according to Islamic Principles as have appropriated by Al-Qur'an and Hadits teachings. Keywords: product, price, location or distribution, customer's loyalty.

\footnotetext{
ABSTRAK

Pemasaran Syari'ah adalah sebuah disiplin bisnis strategis yang mengarahkan proses penciptaan, penawaran dan perubahan value dari suatu inisiator kepada stakeholders-nya yang dalam keseluruhan prosesnya sesuai dengan akad dan prinsip-prinsip mu'amalah (bisnis) dalam Islam. Demikian juga dengan kepuasan pelanggan yang mana merupakan suatu konsep dasar dalam pemasaran dan sebagai keberhasilan organisasi dan suatu bisnis. Hal tersebut dapat diamati dari berbagai usaha yang dilakukan oleh perusahaan dalam menitikberatkan usahanya untuk memberikan kepuasan yang tinggi kepada pelanggannya. Sebagian besar perusahaan mengukur kepuasan pelanggannya dan berharap jika tingkat kepuasan pelanggan tinggi maka pelanggan akan memilih
} 
perusahaannya sehingga akan menyebabkan loyalitas pelanggan terhadap perusahaan. Penelitian ini dimaksudkan untuk mengukur pengaruh keempat bauran pemasaran yang terdiri produk, harga, lokasi/ distribusi, dan promosi terhadap kepuasan pelanggan dan kesesuaian keempat bauran pemasaran tersebut terhadap ajaran Islam. Serta mengukur pengaruh tingkat kepuasan pelanggan terhadap loyalitas pelanggan di Karita Muslim Square Yogyakata. Penelitian ini merupakan penelitian deskriptif analitik dengan pendekatan kuantitatif dan kualitatif menggunakan metode penyebaran kuesioner untuk memperoleh data primer dengan teknik non probability sampling untuk 100 responden pelanggan Karita Muslim Square Yogyakarta. Hasil penelitian ini menunjukkan bahwa produk dan harga berpengaruh secara positif dan signifikan terhadap Kepuasan Pelanggan, namun lokasi/distribusi berpengaruh secara negatif dan tidak signifikan terhadap Kepuasan Pelanggan dengan nilai koefisien regresi beta sebesar -0.26, sedangkan promosi berpengaruh positif dan tidak signifikan terhadap Kepuasan Pelanggan dengan nilai signifikansi sebesar 0.467 > á (0.05). Adapun aspek yang paling kuat pengaruhnya terhadap kepuasan pelanggan adalah harga, dengan nilai signifikansi alpha (á) sebesar 0,000. Sedangkan hasil regresi sederhana didapatkan hasil bahwa kepuasan pelanggan berpengaruh positif dan signifikan terhadap loyalitas pelanggan. Keempat aspek bauran pemasaran yang ditawarkan oleh Karita Muslim Square telah mengikuti ajaran Syari'ah Islam karena telah sesuai dengan ajaran Al-Our'an dan Al-Hadits.

Kata Kunci: aspek produk, aspek harga, aspek lokasi/distribusi, loyalitas pelanggan.

\section{PENDAHULUAN}

Dalam pandangan Islam, perdagangan atau jual beli adalah sebagian dari pekerjaan bisnis dan mendapat tempat terhormat dalam ajaran agama. Nabi Muhammad SAW pernah ditanya: "Mata pencaharian apakah yang paling baik, Ya Rasulullah? Jawab beliau: ialah seseorang yang bekerja dengan tangannya sendiri dan setiap jual beli yang bersih (HR. Al Bazzar).” Namun dalam berbisnis kebanyakan masyarakat selalu ingin mencari laba besar. Jika hal ini yang menjadi tujuan usahanya, maka sering sekali mereka menghalalkan berbagai cara. Sehingga sering terjadi perbuatan negatif yang akhirnya menjadi kebiasaan

Tjiptono mendefinisikan kepuasan konsumen sebagai: "tingkat perasaan seseorang setelah membandingkan kinerja atau hasil yang dirasakannya dengan harapannya." Pendapat lain mengatakan bahwa kepuasan konsumen merupakan hal yang sangat penting untuk mencapai keberhasilan dari suatu badan usaha. Seorang konsumen dikatakan setia dan loyal apabila menunjukkan perilaku pembelian secara teratur atau terdapat suatu kondisi dimana mewajibkan pelanggan membeli paling sedikit dua kali dalam selang waktu tertentu. Dan pada kondisi ini konsumen tersebut dapat disebut sebagai pelanggan. ${ }^{2}$

Berpenampilan modis namun tetap syar' $i$ menjadi trend masa kini mulai dari anakanak hingga orang dewasa. Dengan berbusana muslim dan muslimah akan menyelamatkan generasi umat, bangsa dan agama. Jilbab adalah pakaian yang disyari'atkan oleh Islam, telah menjadi peraturan Allah SWT bagi wanita muslimah dan mu'minah. Sebagaimana Allah SWT telah berfirman dalam Al-Qur'an surat Al-Ahzab: 59:

"Wahai Nabi, katakanlah kepada istri-istrimu, anak-anak perempuanmu dan istri orang-orang mukmin. Hendaklah mereka menutupkan jilbabnya ke seluruh tubuh mereka, yang demikian itu agar mereka lebih mudah untuk dikenali sehingga mereka tidak diganggu, dan Allah SWT Maha Pengampun lagi Maha Penyayang".

Oleh karenanya, kelahiran Karita Muslim Square sebagai sebuah toko penyedia produk busana muslim muda (usia 15 sampai dengan 25 tahun) hadir dengan semangat memenuhi 
kebutuhan selera segmen remaja muda akhwat (wanita) dan ikhwan (lelaki). Karita memprioritaskan menggarap segmen muslim muda. Sebab, di Yogyakarta perusahaan busana muslim yang mengkonsentrasikan diri pada segmen kaum Muslim muda belumlah signifikan. Sebagai sebuah perusahaan busana yang juga berkomitmen mengembangkan syi'ar Islam,

Dalam memasarkan produk dan layanannya, Karita telah mengupayakan strategi pemasaran lengkap beserta keempat elemen bauran pemasarannya. Namun, keempat bauran pemasaran tersebut tampaknya belum memberikan kepuasan yang signifikan terhadap pelanggan, disebabkan karena lokasi dan cabang outlet yang baru dibuka di Yogyakarta dan Surabaya saja, sehingga membuat pelanggan yang berada di luar kota sedikit mengalami kesulitan dalam memperoleh produk yang mereka inginkan mengingat produk yang ditawarkan sangat menarik minat pembeli.

Berdasarkan uraian diatas, segmen pasar sasaran telah ditetapkan, maka strategi yang masih perlu dikembangkan adalah pengembangan bauran pemasarannya. Dengan demikian penulis tertarik untuk meneliti lebih lanjut mengenai tingkat loyalitas pelanggan berdasarkan kepuasan yang dipengaruhi oleh bauran pemasaran di Karita Muslim Square sehingga proses pemasaran dapat berjalan seefektif dan seefisien mungkin serta mampu memberikan kepuasan yang optimal kepada pelanggan yang kemudian dapat meningkatkan loyalitas pelanggan.

\section{Konseptualisasi}

Astrid Kusumowidagdo dalam penelitiannya mengenai Store Atmosphere sebagai taktik implementasi strategi bauran pemasaran retail pada tahap-tahap situasi dalam perilaku belanja konsumen, menyimpulkan bahwa Store Atmosphere memiliki peranan penting dalam menciptakan situasi toko dan merupakan media yang efektif sebagai taktik dalam tiap situasi perilaku pembelian dimana dalam pemasaran produknya terdapat strategi bauran pemasaran. Khan dan Louie meneliti tentang efek dari promosi harga dalam penjualan. ${ }^{3}$ Peneliti menemukan konsep bahwa promosi di dalam toko mempengaruhi pangsa pasar setelah promosi dilakukan yaitu fungsi harga dalam membantu para pembeli untuk memutuskan cara memperoleh manfaat atau utilitas tertinggi yang diharapkan. Dengan demikian, adanya promosi harga dapat membantu para pembeli untuk memutuskan cara mengalokasikan daya belinya pada berbagai jenis barang dan jasa.

\section{Konsep Pemasaran}

Pemasaran adalah satu proses sosial dimana individu dan kelompok mendapatkan apa yang mereka butuhkan dan ingin dengan menciptakan dan mempertukarkan produk dan nilai dengan individu dan kelompok lainnya. ${ }^{4}$ Sedangkan pemasaran syari'ah menurut Kartajaya dan Sula (2006) adalah sebuah disiplin bisnis strategis yang mengarahkan proses penciptaan, penawaran, dan perubahan value dari suatu inisiator kepada stakeholders-nya, yang dalam keseluruhannya prosesnya sesuai dengan akad dan prinsip-prinsip mu'amalah (bisnis) dalam Islam dan tidak mengandung unsur riba, kezaliman, spekulasi, ketidakjelasan dan penipuan (gharar, dan tadlis), judi (maisir), materi yang diharamkan, 
riswah (sogok), maksiat. Memenuhi unsur amanah, kualitas, professional, inovatif, estetika, fair dan akhlaqul karimah, serta transaksinya harus dilakukan sesuai akad yang diperbolehkan dalam Islam, Tjahjono (2009).

\section{Bauran Pemasaran (Marketing Мix)}

Salah satu startegi pemasaran yang sangat berperan dalam mewujudkan tujuan dari badan usaha adalah bauran pemasaran (marketing mix). Bauran pemasaran sendiri merupakan kombinasi dari empat variabel atau kegiatan yang merupakan inti dari sistem pemasaran badan usaha dan yang dapat digunakan badan usaha untuk menjangkau konsumen yang merupakan sasaran pasarnya. Kotler mengemukakan bahwa: "Marketing mix is the set of marketing tools that firm uses to persue its marketing objectives in the target market". 5 Pengertian tersebut mengindikasikan bahwa bauran pemasaran adalah suatu bagian dari alat pemasaran dimana digunakan pada suatu badan usaha untuk mengejar tingkat penjualan yang diinginkan dalam pasar sasaran dan dapat memuaskan keinginan konsumen.

\section{Produk}

Dalam perspektif syari'ah, untuk komponen tawaran (offers) yaitu produk didasari dengan nilai kejujuran dan keadilan; sesuai dengan prinsip-prinsip syari'ah. Kualitas produk yang diberikan harus sesuai dengan yang ditawarkan. Jadi sangat dilarang bagi perusahaan menyembunyikan kecacatan dari produk-produk yang mereka tawarkan. ${ }^{6}$

\section{Harga}

Basu Swastha, (1999) mengemukakan bahwa di dalam pemasaran syari'ah, dimana harga sebagai komponen tawaran (offer), dalam menentukan harga perusahaan haruslah mengutamakan nilai keadilan. Jika kualitas produknya bagus, harganya tentu bisa tinggi. Sebaliknya, jika seseorang telah mengetahui keburukan yang ada di balik produk yang ditawarkan, harganya pun harus sesuai disesuaikan dengan kondisi produk tersebut.

\section{Lokasi/Distribusi}

Sebagaimana telah dijelaskan oleh Kartajaya dan Sula (2006), dimana distribusi/ lokasi merupakan komponen akses (access) sangat berpengaruh terhadap bagaimana usaha dari perusahaan dalam menjual produk dan harganya. Maka dalam menentukan lokasi atau saluran distribusi, perusahaan harus mengutamakan tempat-tempat yang sesuai dengan target pasar sehingga dapat berjalan secara efektif dan efisien. Pada masa Rosulullah SAW telah ada kecenderungan orang-orang untuk memotong jalur distribusi. Hal ini tidak luput dari perhatian beliau SAW. Nabi Muhammad SAW melarang menyongsong (mencegat) pedagang (sebelum tiba di pasar), dan melarang orang kota membeli dagangan orang desa. Inti dari pelarangan tersebut adalah untuk menghindarkan adanya tengkulak (perantara). ${ }^{?}$

\section{Promosi}

Pada dasarnya kesesuaian antara promosi dengan praktik pemasaran yang dilakukan merupakan inti dari pemasaran syariah. Sebagaimana Islam mengajarkan kepada para pengusaha bahwa dalam memasarkan produk dan jasa tidak melebih-lebihkan dengan maksud untuk memikat para pembeli. Nabi Muhammad SAW dengan tegas menyatakan bahwa seorang penjual harus menjauhkan 
diri dari sumpah-sumpah yang berlebihan dalam menjual suatu barang. Beliau pun tidak pernah melakukan sumpah untuk melariskan dagangannya. Beliau Rasulullah SAW bersabda: "Sumpah yang diucapkan untuk melariskan perniagaan, dapat merusak keuntungan." (HR. Muslim, dari Abu Hurairah Ra).

\section{Kepuasan Pelanggan}

Oliver juga mendefinisikan bahwa kepuasan adalah tanggapan pelanggan atas terpenuhinya kebutuhannya. Hal ini berarti penilaian bahwa suatu bentuk keistimewaan dari suatu barang atau jasa ataupun barang/ jasa itu sendiri, memberikan tingkat kenyamanan yang terkait dengan pemenuhan suatu kebutuhan, termasuk pemenuhan kebutuhan di bawah harapan atau pemenuhan kebutuhan melebihi harapan pelanggan. ${ }^{8}$

\section{Loyalitas Pelanggan}

Konsep loyalitas pelanggan lebih banyak dikaitkan dengan perilaku (behavior) daripada dengan sikap. Loyalitas menunjukkan kondisi dari durasi waktu tertentu dan mensyaratkan bahwa tindakan pembelian terjadi tidak kurang dari dua kali. Loyalitas konsumen secara umum diartikan sebagai kesetiaan seseorang atas suatu produk, baik barang maupun jasa tertentu. Loyalitas pelanggan merupakan manifestasi dan kelanjutan dari kepuasan konsumen dalam menggunakan fasilitas maupun jasa pelayanan yang diberikan oleh pihak perusahaan, serta untuk tetap menjadi konsumen perusahaan tersebut.

\section{METODE PENELITIAN}

Penelitian ini dilakukan di Toko Busana
Muslim Karita Muslim Square, Jalan Simanjuntak No 73 Yogyakarta yang berdekatan dengan Universitas Gadjah Mada dan juga Mirota Kampus. Pengumpulan data dilakukan dalam rentang waktu bulan Juni sampai Juli 2011, hari senin sampai minggu.

Metode pengumpulan data dalam penelitian ini adalah (1) Observasi, (2) interviu, (3) Kuesioner, dan (4) Dokumenter. Cara penentuan Sampel dan Populasi pada penelitian ini adalah dengan menggunakan metode nonprobabilitas. Yaitu non probability sampling dengan metode convenience sampling. Populasi penelitian terdiri dari konsumen atau pelanggan yang berkunjung ke Karita Muslim Square Yogyakarta. Penelitian terbatas pada konsumen maupun pelanggan yang datang berkunjung ke Karita Muslim Square pada saat data dikumpulkan yang berjumlah sebanyak 100 orang.

Pengolahan data merupakah salah satu rangkain kegiatan penelitian setelah pengumpulan data. Pengolahan data penelitian yang sudah diperoleh dimaksudkan sebagai suatu cara mengorganisasikan data sedemikian rupa sehingga dapat dianalisa, dibaca dan dapat di tafsirkan. Tahapan pengolahan data dalam penelitian ini adalah (1) Pemeriksaan Data, (2) Pemberian Tanda Kode, dan (3) Tabulasi. Analisis data yang digunakan dalam penelitian ini meliputi analisis deskriptif, analisis kuantitatif atau statistika, dan analisis kualitatif. Analisis deskriptif digunakan untuk mendeskripsikan karakteristik responden, dan deskriptif terhadap variabel penelitian. Analisis statistika digunakan untuk melakukan pengujian hipotesis mengenai pengaruh bauran pemasaran terhadap kepuasan pelanggan yaitu menggunakan analisis regresi linier berganda. Sedangkan 
TABEL 1

VIF MASING-MASING VARIABEL BEBAS

\begin{tabular}{lll}
$\begin{array}{l}\text { VARIABEL } \\
\text { BEBAS }\end{array}$ & VIF & KETERANGAN \\
\hline Produk & 1,508 & Tidak terjadi multikolinearitas \\
\hline Harga & 1,362 & Tidak terjadi multikolinearitas \\
\hline Lokasi & 1,308 & Tidak terjadi multikolinearitas \\
\hline Promosi & 1,196 & Tidak terjadi multikolinearitas \\
\hline & Sumber: Data Primer (diolah)
\end{tabular}

untuk melakukan pengujian hipotesis mengenai pengaruh kepuasan pelanggan terhadap loyalitas pelanggan menggunakan analisis regresi sederhana. Serta untuk menganalisis mengenai kesesuaian antara bauran pemasaran yang terdiri dari produk, harga, lokasi dan promosi terhadap syari'ah Islam, penulis menggunakan Firman Allah (ayat-ayat) yang terdapat dalam Al-Qur'an dan Hadits Nabi Muhammad SAW sebagai alat analisis.

\section{PENGUJIAN HIPOTESIS}

\section{a. Uji $F$}

Menurut Algifari pengujian ini dilakukan untuk mengetahui apakah semua variabel independen mempunyai pengaruh yang sama terhadap variabel dependen. Pengujian yang dilakukan adalah dengan menggunakan uji distribusi F. Yaitu dengan membandingkan antara nilai kritis $\mathrm{F}\left(\mathrm{F}_{\text {tabel }}\right)$ dengan nilai $\mathrm{F}_{\text {hitung }}$ (Rasio F) yang terdapat pada tabel analysis of variance (ANOVA) dari hasil perhitungan.

\section{b. Uji t}

Menurut Kuncoro (2007) uji statistik t pada dasarnya menunjukkan seberapa jauh pengaruh satu variabel penjelas secara individual dalam menerangkan variabel terikat.

\section{c. Koefisien Determinasi $\left(R^{2}\right)$}

Menurut Algifari koefisien determinasi adalah salah satu nilai statistik yang dapat digunakan untuk mengetahui apakah ada hubungan pengaruh antara dua variabel. Nilai koefisien determinasi menunjukkan persentasi variasi nilai variabel dependen yang dapat dijelaskan oleh persamaan regresi yang dihasilkan.

\section{Uji Asumsi Klasik}

Model regresi yang diperoleh dari metode kuadrat terkecil biasa (Ordinary Least Squares/ OLS) merupakan model regresi yang menghasilkan estimator linear tidak bias yang terbaik (Best Linear Unbias Estimator/BLUE). Ada beberapa asumsi yang akan dibahas meliputi (1) uji asumsi berkaitan dengan adanya hubungan antara variabel independen di dalam regresi berganda (multikolinieritas); (2) uji adanya varian residual yang tidak konstan (heteroskedastisitas); dan (3) uji normalitas dengan menggunakan rasio skewness dan rasio kurtosis.

\section{Uji Multikolinearitas}

Pengujian terhadap adanya multikolinearitas dilakukan dengan menggunakan uji VIF (Variance Inflantion Factor). Adapun kriterianya adalah, jika suatu variabel bebas memiliki nilai $\mathrm{VIF}<10$ maka dapat disimpulkan bahwa variabel bebas tersebut tidak mengalami multikolinearitas dengan variabel bebas yang lain.

Nilai VIF untuk masing-masing variabel 
TABEL 2

UJI HETEROSKEDASTISITAS

\begin{tabular}{|c|c|c|c|c|c|c|}
\hline \multirow{2}{*}{\multicolumn{2}{|c|}{ MODEL }} & \multicolumn{2}{|c|}{$\begin{array}{l}\text { UNSTANDARDIZED } \\
\text { COEFFICIENTS }\end{array}$} & $\begin{array}{l}\text { STANDARDIZED } \\
\text { COEFFICIENTS }\end{array}$ & \multirow[t]{2}{*}{$T$} & \multirow[t]{2}{*}{ SIG. } \\
\hline & & B & STD. ERROR & BETA & & \\
\hline \multirow{5}{*}{1} & (Constant) & 0.819 & 0.326 & & 2.511 & 0.014 \\
\hline & Produk & 0.006 & 0.019 & 0.041 & 0.334 & 0.739 \\
\hline & Harga & -0.046 & 0.021 & -0.248 & -2.129 & 0.036 \\
\hline & Lokasi & -0.007 & 0.026 & -0.031 & -0.274 & 0.785 \\
\hline & Promosi & 0.002 & 0.031 & 0.008 & 0.072 & 0.943 \\
\hline \multicolumn{7}{|c|}{ Dependent Variable: abresid } \\
\hline
\end{tabular}

Sumber: Data Primer (diolah)

TABEL 3

HASIL UJ NORMALITAS

\begin{tabular}{lllll} 
& \multicolumn{2}{c}{ SKEWNESS } & & KURTOSIS \\
& STATISTIC & STD. ERROR & STATISTIC & STD. ERROR \\
\hline Unstandardized Residual & 0.030 & 0.241 & 1.042 & 0.478 \\
\hline Valid N (listwise) & & & & \\
\hline
\end{tabular}

bebas disajikan dalam Tabel 1. Berdasarkan nilai VIF yang disajikan dalam Tabel 1 di atas tampak bahwa masing-masing variabel bebas memiliki $\mathrm{VIF}<10$, sehingga dapat dipastikan bahwa masing-masing variabel bebas tersebut tidak terjadi multikolinearitas.

\section{Uji Heteroskedastisitas}

Uji heteroskedastisitas bertujuan untuk menguji apakah dalam model regresi terjadi ketidaksamaan variance dari residual satu pengamatan ke pengamatan yang lain. Jika variance dari residual satu pengamatan ke pengamatan lain tetap, maka disebut homoskedastisitas dan jika berbeda disebut heteroskedastisitas. Model regresi yang baik adalah yang homoskedastisitas atau tidak terjadi heteroskedastisitas. ${ }^{9}$ Pada penelitian ini digunakan uji Glejser untuk mendektesi ada atau tidaknya heteroskedastisitas. Hasil uji heteroskedastisitas dengan menggunakan uji Glejser adalah sebagai berikut. (lihat tabel 2)

Dari tabel diatas dapat diketahui bahwa ketiga variabel independen bebas dari masalah Heteroskedastisitas kecuali pada variabel harga mengalami heteroskedastisitas karena nilai signifikansinya lebih kecil 0,05 yaitu 0,036 . Sedangkan nilai signifikansi ketiga variabel independen lainnya (produk, lokasi dan promosi) lebih besar dari nilai signifikansi 0,05.

\section{Uji Normalitas}

Uji normalitas digunakan untuk mengetahui apakah data berdistribusi normal atau tidak dengan menggunakan rasio skewness dan rasio kurtosis. Rasio skewness adalah nilai skewness dibagi dengan standard error skewness sedangkan rasio kurtosis adalah nilai kurtosis dibagi dengan standard error kutorsis. Sebagai pedoman, apabila rasio kurtosis dan skewness berada diantara -2 hingga +2 , maka distribusi data adalah normal. ${ }^{10}$ Maka nilai rasio kurtosis dan skewness dalam penelitian ini disajikan pada tabel 3 .

Dari tabel 3 tersebut dapat diketahui 
TABEL 4

HASIL ANALISIS REGRESI LINIER BERGANDA

PENGARUH BAURAN PEMASARAN TERHADAP KEPUASAN PELANGGAN

\begin{tabular}{|c|c|c|c|}
\hline $\begin{array}{l}\text { VARIABEL } \\
\text { BEBAS }\end{array}$ & $\begin{array}{l}\text { STANDARDIZED } \\
\text { COEFFICIENT }(\beta)\end{array}$ & $\mathrm{T}$ & SIG \\
\hline Konstanta C & - & 1.779 & 0.078 \\
\hline Produk (X1) & 0.236 & 2.406 & 0.018 \\
\hline Harga (X2) & 0.465 & 4.993 & 0.000 \\
\hline Lokasi (X3) & -0.26 & -0.289 & 0.773 \\
\hline Promosi (X4) & 0.064 & 0.730 & 0.467 \\
\hline \multicolumn{4}{|c|}{ Variabel terikat : Kepuasan Pelanggan $(\mathrm{Y})$} \\
\hline $\begin{array}{l}R^{2} \text { adj } \\
\text { F hitung } \\
N\end{array}$ & \multicolumn{3}{|c|}{$\begin{array}{l}0.368 \\
15,428 ; \text { sig }=0.000 ; \text { Durbin }- \text { Watson }=1.494 \\
100\end{array}$} \\
\hline
\end{tabular}

bahwa rasio skewness sebesar $0.030 / 0.241=$ 0.124 sedangkan rasio kurtosis sebesar 1.042 $/ 0.478=2,1$. Karena rasio skewness dan rasio kurtosis berada diantara -2 hingga +2 , maka dapat disimpulkan bahwa distribusi data adalah normal.

\section{PEMBAHASAN DAN ANALISA DATA}

Pengaruh Produk, Harga, Lokasi dan Promosi terhadap Kepuasan Pelanggan

Hasil analisis regresi linier berganda yang menyatakan pengaruh dari Bauran pemasaran (produk, harga, lokasi dan promosi) terhadap Kepuasan Pelanggan disajikan dalam Tabel 4.

Dari hasil uji F menunjukkan F hitung sebesar 15,428 dan F tabel sebesar 2,47 pada $\mathrm{a}=0,05$. Besarnya $\mathbf{R}^{2}$ yang dihasilkan menunjukkan nilai sebesar 0,394 atau 39,4 persen dan oleh karena F hitung masih lebih besar dari pada F tabel, maka model tersebut menghasilkan uji $\mathrm{F}$ yang menjelaskan bahwa model signifikan secara statistik pada a $=$ 0,05, didukung oleh nilai signifikansi $\mathrm{F}$ hitung sebesar 0,000 , sehingga dapat disimpulkan bahwa variasi pada variabel dependen yaitu kepuasan pelanggan sebesar
$36,8 \%$ dijelaskan oleh variasi independen dan sisanya sebesar $63,2 \%$ tidak dijelaskan pada model.

Berdasarkan hasil koefisien regresi diatas, estimasi model empirik diperoleh hasil sebagai berikut:

$Y_{1}=0.236 X_{1}+0.465 X_{2}-0.26 X_{3}+0.064 X_{4}$

\section{Pengujian Hipotesis Pertama}

Berdasarkan hasil regresi linier berganda yang disajikan dalam tabel 4 produk $\left(\mathrm{X}_{1}\right)$ memiliki koefisien regresi baku $\beta_{1}=0.236$ dengan $p=0.018$. Karena $\mathrm{p}=0.018<$ á $(0.05)$ $\mathrm{makaH}_{\mathrm{a} 1}$ diterima danH $\mathrm{H}_{\mathrm{o}}$ ditolak. Dengan demikian dapat disimpulkan bahwa, Produk berpengaruh positif dan signifikan terhadap Kepuasan Pelanggan. Artinya, jika persepsi pelanggan terhadap produk semakin baik maka kepuasannya juga semakin tinggi, atau sebaliknya, jika persepsi pelanggan terhadap produk semakin tidak baik maka kepuasannya semakin rendah.

\section{Pengujian Hipotesis Kedua}

Berdasarkan hasil regresi linier berganda 
yang disajikan dalam tabel 5.13 harga $\left(\mathrm{X}_{2}\right)$

memiliki koefisien regresi baku $\beta_{2}=0.465$

dengan $\mathrm{p}=0.000$. Karena $\mathrm{p}=0.000<$ á $(0.05)$

makaH $_{\mathrm{a} 2}$ diterima danH $\mathrm{o}_{2}$ ditolak. Dengan

demikian dapat disimpulkan bahwa, harga

berpengaruh positif dan signifikan terhadap

Kepuasan Pelanggan. Artinya, jika persepsi

pelanggan terhadap harga semakin baik

maka kepuasannya juga semakin tinggi, atau sebaliknya, jika persepsi pelanggan terhadap harga semakin tidak baik maka kepuasannya semakin rendah.

\section{Pengujian Hipotesis Ketiga}

Berdasarkan hasil regresi linier berganda yang disajikan dalam tabel 5.13 harga $\left(\mathrm{X}_{3}\right)$ memiliki koefisien regresi baku $\beta_{3}=-0.26$ dengan $\mathrm{p}=0.773$. Karena $\mathrm{p}=0.773>$ á (0.05) makaH $_{\mathrm{a} 5}$ ditolak danH $\mathrm{H}_{\mathrm{o}}$ diterima. Dengan demikian dapat disimpulkan bahwa, Lokasi/ distribusi berpengaruh negatif dan tidak signifikan terhadap Kepuasan Pelanggan. Artinya bahwa 1 satuan deviasi standar dalam perubahan lokasi/distribusi diharapkan mengakibatkan perubahan deviasi standar 0.26 dalam kepuasan pelanggan.

\section{Pengujian Hipotesis Keempat}

Berdasarkan hasil regresi linier berganda yang disajikan dalam tabel 5.13 harga $\left(\mathrm{X}_{4}\right)$ memiliki koefisien regresi baku $\beta_{4}=0.064$ dengan $p=0.467$. Karena $p=0.467>$ á $(0.05)$ $\mathrm{makaH}_{\mathrm{a} 7}$ ditolak danH $\mathrm{o}_{\mathrm{o}}$ diterima. Dengan demikian dapat disimpulkan bahwa, promosi berpengaruh positif namun tidak signifikan terhadap Kepuasan Pelanggan. Hal ini berarti bahwa peningkatan kepuasan pelanggan akan diikuti dengan peningkatan promosi dan sebaliknya penurunan kepuasan pelanggan akan diikuti dengan penurunan promosi.

\section{Pengaruh Kepuasan Pelanggan terhadap Loyalitas Pelanggan}

Hasil analisis regresi linier sederhana yang menyatakan pengaruh dari Kepuasan Pelanggan terhadap Loyalitas Pelanggan disajikan dalam Tabel 5.

Model regresi yang disajikan dalam Tabel 5 memiliki statistik $\mathrm{F}=18,646$ dengan $\mathrm{p}=$ 0.000. Karena $\mathrm{p}(0.000)<a(0.05)$ nilai statistik F tersebut signifikan, yang berarti Kepuasan Pelanggan berpengaruh signifikan terhadap Loyalitas Pelanggan.

Nilai koefisien determinasi disesuaikan $\left(\mathbf{R}^{2}\right.$ adj $)=0.160$ atau $16.0 \%$. Hal ini dapat diinterpretasikan bahwa, tinggi rendahnya Loyalitas Pelanggan 16.0\% disebabkan oleh perubahan yang terjadi pada Kepuasan Pelanggan, sedangkan sisanya $84 \%$ disebabkan oleh variabel-variabel lain yang tidak tercakup dalam model regresi tersebut.

Berdasarkan hasil koefisien regresi diatas, estimasi model empirik diperoleh hasil sebagai berikut:

$$
Y_{2}=0.4 X_{1}
$$

\section{Pengujian Hipotesis Kelima}

Berdasarkan hasil analisis regresi linier sederhana yang disajikan dalam Tabel 2. Kepuasan Pelanggan (X) memiliki koefisien regresi baku â $=0.400$ dengan $\mathrm{p}=0.000$. Karena $\mathrm{p}=0.000<$ á $(0.05) \mathrm{makaH}_{\mathrm{a} 5}$ diterima dan $_{o 5}$ ditolak. Dengan demikian dapat disimpulkan bahwa, Kepuasan Pelanggan berpengaruh positif dan signifikan terhadap Loyalitas Pelanggan. Artinya, jika kepuasan pelanggan semakin tinggi maka 
TABEL 5

HASIL ANALISIS REGRESI LINIER

PENGARUH KEPUASAN PELANGGAN TERHADAP LOYALITAS PELANGGAN

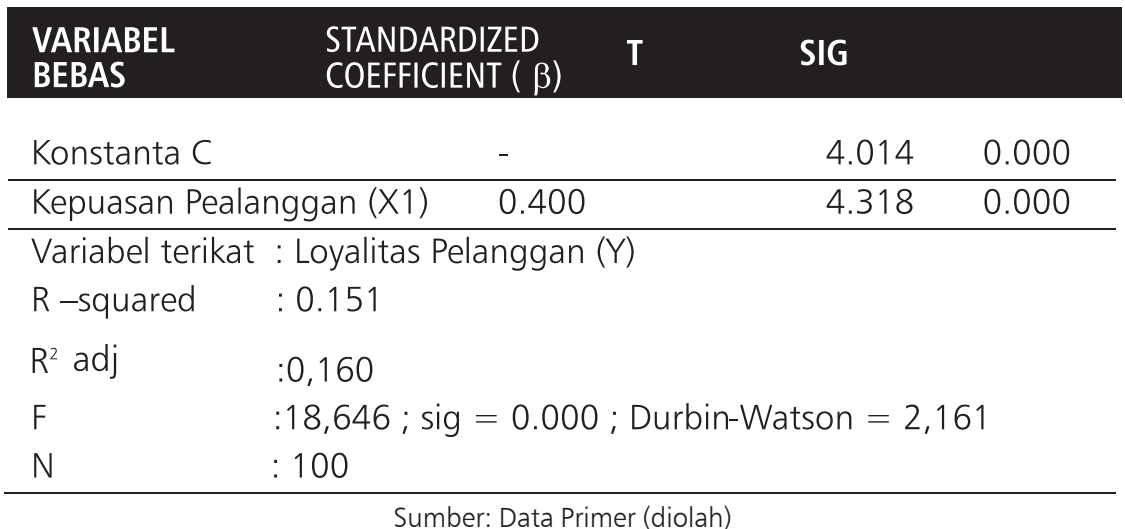

loyalitasnya akan semakin tinggi juga, atau sebaliknya, jika kepuasan pelanggan semakin rendah maka loyalitasnya cenderung akan semakin rendah.

\section{Kesesuaian Keempat Bauran Pemasaran terhadap Syari'ah Islam}

Untuk menganalisis mengenai kesesuaian antara bauran pemasaran yang terdiri dari produk, harga, lokasi dan promosi terhadap syari'ah Islam, penulis menggunakan Firman Allah (ayat-ayat) yang terdapat dalam AlQur'an dan Hadits Nabi Muhammad SAW sebagai alat analisis.

\section{Pengujian Hipotesis Keenam}

Ditinjau dari perspektif Islam, produk yang ditawarkan oleh Karita Muslim Square Yogyakarta telah sesuai dengan syarat marketing Syari'ah, mengingat produk yang ditawarkan adalah produk-produk baik busana Muslim-Muslimah yang keseluruhannya didesain untuk menutup aurat maupun segala peralatan untuk beribadah lengkap dengan aksesorisnya dapat menjadikan para pelanggan akan terlihat indah dalam berbusana. Sebab dalam sebuah hadist disebutkan bahwasanya sesungguhnya Allah itu menyukai keindahan. Adapun produk busana muslim dan muslimah tampak sesuai dengan syari'ah dimana model yang disajikan tidak ketat membentuk tubuh dengan bahan kain yang tidak terlalu tipis namun masih terkesan modis dan elegan.

Sebagaimana Allah SWT telah berfirman dalam Al-Qur'an Surat Al-Ahzab: 59.

"Wahai Nabi, katakanlah kepada istri-istrimu, anak-anak perempuanmu dan istri orang-orang mukmin. Hendaklah mereka menutupkan jilbabnya ke seluruh tubuh mereka, yang demikian itu agar mereka lebih mudah untuk dikenali sehingga mereka tidak diganggu, dan Allah SWT Maha Pengampun lagi Maha Penyayang".

\section{Pengujian Hipotesis Ketujuh}

Untuk menguji hipotesis ini penulis menggunakan dalil dari Al-Qur'an dan AlHadits yang dilakukan dengan observasi secara langsung pada obyek penelitian yaitu Karita Muslim Square Yogyakarta.

Allah SWT berfirman dalam Al-Qur'an surat An-Nahl ayat 90:

"Sesungguhnya Allah menyuruh (kamu) 
Berlaku adil dan berbuat kebajikan, memberi kepada kaum kerabat, dan Allah melarang dari perbuatan keji, kemungkaran dan permusuhan. Dia memberi pengajaran kepadamu agar kamu dapat mengambil pelajaran”

Adapun analisis syari'ah mengenai kelayakan mengambil keuntungan di Karita Muslim Square Yogyakarta tidak dapat dilaksanakan karena penulis tidak dapat memperoleh data akan hal tersebut. Sebab segala hal yang berkaitan dengan harga merupakan rahasia perusahaan yang hanya dapat diberitahukan kepada pihak-pihak tertentu. Untuk mengetahui sebagian besar pendapat konsumen mengenai keterjangkauan harga, kesesuaian harga dengan kualitas barang, dan kepuasan konsumen atas harga, penulis menggunakan rata-rata (mean) dari keseluruhan pendapat konsumen untuk menganalisisnya.

Berdasarkan atas perolehan rata-rata (mean) jawaban dari responden berdasarkan skala likert didapatkan bahwa rata-rata menunjukkan point lebih dari 3 dimana point tersebut mendekati point 5 yang berarti bahwa konsumen merasa puas terhadap harga yang ditawarkan oleh pihak Karita Muslim Square karena harga yang disajikan sesuai dengan kualitas barang dan dapat dijangkau oleh berbagai segmen. Dengan demikian, dapat penulis simpulkan bahwa harga yang ditawarkan oleh Karita Muslim Square telah sesuai dengan Syari'ah Islam karena harga pada barang yang ditawarkan sesuai dengan kualitas dan dapat dijangkau oleh berbagai segmen.

\section{Pengujian Hipotesis Kedelapan}

Berdasarkan observasi yang telah dilakukan oleh peneliti, Karita Muslim Square Yogyakarta telah melakukan pendistribusian melalui lokasinya yang strategis berada di tengah kota berdekatan dengan universitas terkemuka Yogyakarta yang mudah dijangkau yaitu di jalan raya C. Simanjuntak. Terdapat area parkir untuk kendaraan bermotor maupun mobil yang cukup luas sehingga tidak mengganggu para pengguna jalan raya lainnya.

Pada masa Rasulullah SAW telah ada kecenderungan orang-orang untuk memotong jalur distribusi. Hal ini tidak luput dari perhatian beliau SAW. Nabi Muhammad SAW melarang menyongsong (mencegat) pedagang (sebelum tiba di pasar), dan melarang orang kota membeli dagangan orang desa. Inti dari pelarangan tersebut adalah untuk menghindarkan adanya tengkulak (perantara). Beliau SAW bersabda: "Tidak boleh orang kota menjadi perantara niaga bagi orang desa. Biarkanlah orang memperoleh rezeki Allah satu sama lainnya" (HR. Muslim dari Jabir).

Sejauh ini penulis melihat bahwa nampaknya lokasi dan proses distribusi Karita Muslim Square telah sesuai dengan syari'ah Islam, dimana baik lokasi dan proses distribusinya tidak mengganggu dan merugikan orang lain.

\section{Pengujian Hipotesis Kesembilan}

Setelah melakukan observasi, sejauh ini peneliti melihat bahwa Karita Muslim Square telah melakukan promosinya secara intensif dengan berbagai usaha untuk mengenalkan dan mempertunjukkan produk-produk yang ditawarkan baik melalui audio maupun visual. Adapun dalam mempromosikan produk-produknya pihak Karita Muslim Square tidak terlalu melebih-lebihkan 
produknya namun tetap konsekuen sesuai dengan kenyataan yang ada.

Sebagaimana Rasulullah SAW dalam menjual pun tidak pernah melebih-lebihkan produk dengan maksud untuk memikat pembeli. Nabi Muhammad SAW dengan tegas menyatakan bahwa seorang penjual harus menjauhkan diri dari sumpah-sumpah yang berlebihan dalam menjual suatu barang. Beliau Nabi Muhammad SAW pun tidak pernah melakukan sumpah untuk melariskan dagangannya. ${ }^{1}$

Nabi Muhammad SAW bersabda: "Sumpah yang diucapkan untuk melariskan perniagaan, dapat merusak keuntungan”. (HR. Muslim dari Abu Huraira Ra).

Hadits tersebut menjelaskan bahwa sumpah yang berlebihan dalam promosi telah sejak dulu dianjurkan untuk dijauhi karena sumpah yang berlebihan yang dilakukan hanya untuk mendapatkan penjualan yang lebih, tidak akan menumbuhkan kepercayaan (trust) pelanggan. Berdasarkan paparan tersebut, dapat diambil kesimpulan bahwa Karita Muslim Square telah melakukan promosi sesuai dengan Syari'ah Islam sebab dalam mempromosikan produknya Karita Muslim Square tidak melakukan kebohongan maupun mempromosikan barang secara berlebihlebihan namun sesuai dengan kenyataan yang ada.

\section{KESIMPULAN}

Dari hasil analisis sebagaimana digambarkan di atas, dapat disimpulkan beberapa hal sebagai berikut:

Pertama, produk berpengaruh positif dan signifikan terhadap kepuasan pelanggan.
Dilihat dari koefisien regresi, dapat diartikan jika persepsi pelanggan terhadap kualitas produk semakin baik maka kepuasannya juga semakin tinggi, atau sebaliknya jika persepsi pelanggan terhadap kualitas produk semakin tidak baik maka kepuasan semakin rendah.

Kedua, harga berpengaruh positif dan signifikan terhadap kepuasan pelanggan. Dilihat dari koefisien regresi, dapat diartikan jika persepsi pelanggan terhadap harga semakin naik maka kepuasannya juga semakin tinggi, atau sebaliknya jika persepsi pelanggan terhadap harga turun maka kepuasan semakin rendah. Artinya bahwa terdapat korelasi antara harga dengan kualitas produk atau prestise misalnya apabila harga naik maka konsumen berpersepsi bahwa kualitas, bahan atau mode produk tersebut semakin bagus, demikian pula apabila harga semakin tinggi maka tingkat kebanggaan prestise konsumen akan semakin tinggi. Harga merupakan suatu variabel yang paling berpengaruh dibandingkan variabelvariabel yang lain seperti produk, lokasi/ distribusi, dan promosi, ini dapat dilihat dari koefisien beta yang mempunyai koefisien beta paling besar yaitu 0.465 , kemudian kedua dipengaruhi oleh produk dimana ditemui besaran koefisien beta sebesar 0.236

Ketiga, lokasi/distribusi berpengaruh secara negatif dan tidak signifikan terhadap kepuasan pelanggan. Sehingga hasil perhitungan mengenai pengaruh antara lokasi/distribusi terhadap kepuasan pelanggan tersebut tidak dapat disimpulkan.

Keempat, promosi berpengaruh positif namun tidak signifikan terhadap kepuasan pelanggan. Dimana didapatkan hasil koefisien regresi sebesar 0.064 . Hal ini berarti bahwa peningkatan kepuasan pelanggan akan diikuti dengan peningkatan promosi 
dan sebaliknya penurunan kepuasan pelanggan akan diikuti dengan penurunan promosi.

Kelima, kepuasan Pelanggan berpengaruh positif dan signifikan terhadap Loyalitas Pelanggan. Dimana didapatkan hasil koefisien regresi sebesar 0.400 . Hal ini berarti bahwa jika kepuasan pelanggan semakin tinggi maka loyalitasnya akan semakin tinggi juga, atau sebaliknya, jika kepuasan pelanggan semakin rendah maka loyalitasnya cenderung akan semakin rendah.

Keenam, produk yang ditawarkan oleh Karita Muslim Square telah mengikuti ajaran Syari'ah karena telah sesuai dengan ajaran yang terdapat di dalam Al-Qur'an dan AlHadits. Dimana produk yang ditawarkan secara keseluruhan memenuhi ketentuan syari'ah, diantaranya ukuran produk yang lebar menutup aurat, bahan yang digunakan tidak tipis dan model produk yang wajar tidak membentuk tubuh.

Ketujuh, harga yang ditawarkan oleh Karita Muslim Square telah mengikuti ajaran Syari'ah karena telah sesuai dengan ajaran yang terdapat di dalam Al-Qur'an dan AlHadits. Dimana Karita Muslim Square tidak melakukan penipuan dalam menetapkan harga sebab harga yang ditawarkan sesuai dengan kualitas produk dan dapat dijangkau oleh berbagai segmen.

Kedelapan, lokasi/Distribusi Karita Muslim Square telah mengikuti ajaran Syari'ah karena telah sesuai dengan ajaran yang terdapat di dalam Al-Qur'an dan Al-Hadits. Dimana Karita Muslim Square telah melakukan pendistribusian melalui lokasinya yang strategis dan mudah dijangkau, serta dengan adanya area parkir yang luas maka tidak mengganggu para pedagang dan pengguna jalan raya lainnya dalam beraktifitas.

Kesembilan, promosi yang dilakukan oleh Karita Muslim Square telah mengikuti ajaran Syari'ah karena telah sesuai dengan ajaran yang terdapat di dalam Al-Qur'an dan AlHadits. Dimana Karita tidak melakukan sumpah atau promosi yang berlebih-lebihan, artinya segala hal yang dipromosikan oleh Karita adalah sesuai dengan produk dan jasa yang ada.

Selanjutnya, berdasarkan kesimpulan yang telah diperoleh dalam penelitian ini, maka penulis menyampaikan saran yang patut diperhatikan oleh pihak Karita Muslim Square Yogyakarta dalam meningkatkan kepuasan dan loyalitas pelanggan dengan meningkatkan promosi akan potonganpotongan harga sehingga akan meningkatkan ketertarikan pelanggan untuk berbelanja dengan demikian akan menimbulkan kepuasan dan loyalitas pelanggan.

Agar memperlancar lalu lintas di depan toko sebaiknya Karita Muslim Square memperluas area parkir khususnya untuk kendaraan bermotor mengingat banyaknya pelanggan yang mengendarai sepeda motor, dan meningkatkan ketertiban dalam memarkir mobil agar tidak terkesan memenuhi jalan di depan toko sehingga tidak mengganggu pengguna jalan lainnya. Untuk menjaga loyalitas, pihak Karita Muslim Square juga perlu memperbanyak lagi koleksi produk muslim dan muslimah yang variatif namun tetap sesuai dengan syari'ah Islam.

\section{CATATAN AKHIR}

1 F, Tjiptono. Strategi Pemasaran. (Yogyakarta: Andi, 1997). h. 24.

2 R.W, Griffin. Management. (Boston: Houghton M.C. 1995). h. 30. 
3 Kahn, E. and Lovie, A., "Effect of Retraction of Price Promotion on Brand Choice Behavior for VarietySeeking and Last-Purchase-Loyal Consumers", Journal of Marketing Research, (August, 1990). h. 279-289.

4 P. Kotler. Manajemen Pemasaran; Analisis, Perencanaan, dan Pengendalian, Jilid I. Edisi Kedelapan. Alih Bahasa Ancella Anitawati Hermawan", (Jakarta: Salemba Empat, 2005). h. 15.

5 Kotler, P., Manajemen Pemasaran. (Jakarta: PT. Prenhallindo. 1997). h. 68.

6 H, Kartajaya. dan SM, Sula. Syari'ah Marketing. (Bandung: Mizan Pustaka. 2006). h.

7 T Gunara dan UH Sudibyo, Marketing Muhammad. (Bandung: Madani Prima. 2007).

8 Oliver, R.L., Satisfaction: A Behavioral Perspective on The Consumer (New York: The McGraw Hill Companies, Inc., 1997)

9 Imam Ghozali. Analisis Multivariate Lanjutandengan Program SPSS. (Semarang: Badan Penerbit Universitas Diponegoro, 2006).

10 Singgih Santoso, Buku Latihan SPSS Statistik Parametik (Jakarta: PT. Gramedia. 2002).

11 T. Gunara dan UH Sudibyo. Marketing Muhammad. (Bandung: Madani Prima. 2007).

\section{DAFTAR PUSTAKA}

Al-Qur'anul Karim

Ghozali, Imam, 2006, "Analisis Multivariate Lanjutan dengan Program SPSS", Semarang, Badan Penerbit Universitas Diponegoro.

Griffin, R.W. 1995, "Management", Boston: Houghton M.C

Gunara, T dan Sudibyo, UH. 2007. "Marketing Muhammad", Bandung: Madani Prima.

Kahn, E and Louie, A. 1990. "Effect of Retraction of Price Promotion on Brand Choice Behavior for Variety-Seeking and Last-Purchase-Loyal Consumers". Journal of Marketing Research. August pp. 279-289.

Kartajaya, H dan Sula, SM. 2006. "Syari'ah Marketing". Bandung: Mizan Pustaka.

Kotler, P. 1997. "Manajemen Pemasaran", Jakarta: PT. Prenhallindo.

- 2005, "Manajemen Pemasaran; Analisis, Perencanaan, dan Pengendalian". Jilid I. Edisi Kedelapan. Alih Bahasa Ancella Anitawati Hermawan. Jakarta: Salemba Empat.

Kuncoro, M. 2003. "Metode Riset Untuk Bisnis dan Ekonomi". Jakarta: Erlangga.

Santoso, Singgih. 2002. "Buku Latihan SPSS Statistik Parametik". Jakarta: PT. Gramedia

Swastha, Basu. 1999. "Saluran Pemasaran". Yogyakarta: BPFE 2000. "Azas-Azas Marketing", Yogyakarta: Liberty.

Tjahjono, G. 2009. "Sharing Magazine", Edisi 30 Thn III Juni 2009, Jakarta.
Tjiptono, F. 1997. "Strategi Pemasaran", Yogyakarta: Andi. and Chandra, G. 2005. "Service, Quality and Satisfaction". Yogyakarta: Andi Offset.

Oliver, R.L. 1997. "Satisfaction: A Behavioral Perspective on The Consumer", New York: The McGraw Hill Companies, Inc. 